\title{
İlkokul Sosyal Bilgiler Ders Kitabının Toplumsal Cinsiyet Açısından İncelenmesi ${ }^{1}$
}

\section{Kadir Sönmez ${ }^{2}$}

\section{Yurdal Dikmenli ${ }^{3}$}

Type/Tür:

Research/Araştırma

Received/Geliş Tarihi: May 4/ 4 May1s 2020

Accepted/Kabul Tarihi: August

26/ 26 Ağustos 2020

Page numbers/Sayfa No: $434-458$

Corresponding

Author/İletişimden Sorumlu

Yazar: kdrsonmez89@gmail.com

\section{$\checkmark$ iThenticate}

This paper was checked for plagiarism using iThenticate during the preview process and before publication. / Bu çalışma ön inceleme sürecinde ve yayımlanmadan önce iThenticate yazılımı ile taranmıştır.

Copyright @ 2017 by Cumhuriyet University, Faculty of Education. All rights reserved.

\section{Öz}

Toplumsallaşma sürecinde bireylerde cinsiyet rolleri önemli olup, bu rollerin oluşmasında okulun ve ders kitaplarının önemi büyüktür. Okul, kültürel ve toplumsal değerlerin aktarıldığı ve tekrar üretildiği ana mekân olarak, toplumsal cinsiyet kimliklerinin de olgunlaştırıldığı bir kurum durumundadır. Toplumsal cinsiyet rollerinin, ilkokul düzeyinde okutulan ve içerik olarak hayatla iç içe olan Sosyal Bilgiler ve Hayat Bilgisi gibi iki önemli ders ve bu derslerde okutulan ders kitapları aracılığı ile yeni nesillere, doğru aktarımının sağlanması oldukça önemlidir. Çalışmanın amacı 2019-2020 eğitim öğretim yılında ilkokul dördüncü sınıfta Sosyal Bilgiler ders kitabının toplumsal cinsiyet açısından değerlendirilmesidir. Bu amaç doğrultusunda 4. sınıf sosyal bilgiler ders kitabındaki metin ve görsellerde; bireylerle özdeşleştirilen nesne ve renklerin, bireylere çizilen davranış kalıpları ve aile içi rollerin, bireylerin meslek seçimlerinin, bireylerin kişisel uğraşı ve eylemlerinin toplumsal cinsiyet açısından değişkenlik gösterme durumlarına; bireylerin toplumun cinsiyetlere bakış açısına göre etken veya edilgen olma durumlarına; dil içinde toplumsal cinsiyetin farklı değişkenlerine göre şekillenmiş olan kalıplaşmış ifadelerin yer alma durumlarına cevap aranmıştır. Bu çalışmada nitel araştırma yöntemlerinden biri olan doküman incelemesi kullanılmıştır. Çalışma boyunca taranan kaynaklardan elde edilen veriler içerik analizi yöntemiyle değerlendirilmiştir. Çalışma sonunda inceleme kapsamında yer alan ders kitabındaki cinsiyet söylemlerinin kullanılış şekli ve toplumsal cinsiyet rollerinin sunuluşunun genel anlamda duyarlılıkla hazırlandığı fakat bu duyarlılık seviyesinin yeterli olmadığı sonucuna ulaşılmıştır.

Anahtar Kelimeler: İlkokul, sosyal bilgiler ders kitabı, toplumsal cinsiyet, doküman incelemesi, içerik analiz

Suggested APA Citation/Önerilen APA Atıf Biçimi:

Sönmez, K. \& Dikmenli, Y. (2021). İlkokul sosyal bilgiler ders kitabının toplumsal cinsiyet açısından incelenmesi. Cumhuriyet International Journal of Education, 10(1), 434-458. http://dx.doi.org/10.30703/cije.732000

$1 \mathrm{Bu}$ çalışma ikinci yazarın danışmanlığında tamamlanmış olan "İlkokul hayat bilgisi ve sosyal bilgiler ders kitaplarının toplumsal cinsiyet açısından incelenmesi" isimli yüksek lisans tezinden üretilmiştir.

2 Sınıf Öğretmeni, Bölükyazı Köyü İlkokulu, Bitlis/ Turkey

Primary Teacher, Bitlis Bölükyazı Village, Bitlis/ Turkey

e-mail: kdrsonmez89@gmail.com ORCID ID: https:// orcid.org/0000-0001-7345-9582

3 Doç. Dr. Kırşehir Ahi Evran Üniversitesi, Eğitim Fakültesi, Temel Eğitim Bölümü, Kırşehir/ Türkiye

Assoc. Prof. Kırşehir Ahi Evran University, Faculty of Education, Department of Primary Education, Kırşehir/ Turkey

e-mail: dikmenliy@hotmail.com ORCID ID: $\underline{\text { https:// orcid.org/0000-0003-3738-3095 }}$ 


\title{
Analysis of Primary School Social Studies Textbook in terms of Gender
}

\begin{abstract}
Gender roles are important for individuals in socialization process and school, and textbooks are important in their formation. The school is an institution where gender identities are matured as main place in where the cultural and social values are transferred and reproduced. It is very important to ensure the transfer of gender roles to new generations through two important lessons taught at primary school and social content and life knowledge that are intertwined with life and textbooks taught in these lessons. The aim of this study is to evaluate the social studies textbook in terms of gender in the fourth year of primary school in the 20192020 academic year. For this aim, in the texts and images of the 4th grade social studies textbook; the gender variation of the objects and colors identified with individuals, behavioral patterns and family roles drawn to individuals, professional choices of individuals, personal occupation and actions of individuals; whether individuals are active or passive according to the gender perspective of the society; an answer was sought for the situation of stereotyped expressions, which were shaped according to the different variables of gender in the language. In this study, document review that is one of the qualitative research methods was used. The data obtained from the sources scanned throughout the study were evaluated using the content analysis method. At the end of the study, it was concluded that the use of gender discourses in the textbook and the presentation of gender roles were prepared via sensitivity in general, but this level of sensitivity was insufficient.
\end{abstract}

Keywords: Primary school, social studies textbook, gender, document review, content analysis

\section{Giriş}

Toplumsal cinsiyet kavramı birbirinden farklı iki sözcüğün birleşiminden oluşmuş ve son yıllarda akademik camiada üzerinde önemle durulan konulardan biri olmuştur. Bu kavramı oluşturan sözcüklerden biri olan "cinsiyet" sözcüğü, yaygın olarak kadın ve erkeği akla getirmektedir. Bu nedenle cinsiyet sözcüğü en temel manasiyla cinslerin kadın ve erkek olarak ayrılmasıdır.

Cinsiyet temsilini tartışırken, "cinsiyet (sex)" ve "toplumsal cinsiyet (gender)" terimlerinin tanımları kullanılmaktadır. Giddens (2008), cinsiyetin erkekler ve kadınlar arasındaki biyolojik veya anatomik bir fark olduğunu belirtirken, "toplumsal cinsiyet", ise erkekler ve kadınlar arasındaki psikolojik, sosyal ve kültürel farklılıklarla ilgilidir. Montgomery (1986) cinsiyet ile toplumsal cinsiyet arasindaki ayrımı şu şekilde açıklar; cinsiyet genetik koda dayanırken, toplumsal cinsiyet erkek ve kadınlar arasındaki dilsel farklılıkları etkileyen sosyal kodları ifade eder.

Toplumsal cinsiyet kavram1, toplumun devreye girerek bireyleri cinsiyetleri üzerinden biçimlendirmeye başlaması ile kendinden söz ettirir. Cinsiyetlerin üzerinde yaratılış rol alırken, toplumsal cinsiyet insanlar ve onların eliyle oluşan kültür aracılığıyla belirlenmektedir. Cinsiyet; erkek ve kadının genetik, fizyolojik ve biyolojik olarak sahip olduğu farklılıkları ifade ederken; toplumsal cinsiyet ise bireylere cinsiyetleri bağlamında bağlı oldukları kültür ve toplumlarca yüklenen beklenti, rol, sorumluluk farklılıklarıdır (Üner, 2008). Toplumsal cinsiyet kavramı esasında biyolojik anlamda kullanılan cinsiyet kelimesi ile karıştırılmaması için kullanılmakta olan bir kavramdır. Zira toplumsal cinsiyet, biyolojik cinsiyet ayrımından daha geniş bir anlam taşır.

Dünyada 20 yüzyıla kadar toplumsal cinsiyet olgusu pek fazla tartışmaya değer bulunmamıştır. 19. yüzyılda ise edebiyat alanında toplumsal cinsiyet dışında daha çok aile ve çocukluğa odaklanıldığı görülmektedir. Ders kitapları genellikle 
geleneksel değerleri yansıtır ve değerleri bir sonraki nesle aktarmak için sosyalleşme aracı olarak kullanılır. Bu dönemde kitapların biri erkekler, diğeri de kızlar için olmak üzere iki gruba ayrıldığı görülmektedir. Cinsiyete uygun davranışları ele alan literatür incelendiğinde özellikle kız veya erkek çocuklar için özel olarak yazılmış kitaplar on dokuzuncu yüzyılın son çeyreğinde artmaya başlamıştır. Erkekler için kitaplar liderliği ve eylemi vurgularken, kızlar için kitaplar kızların itaat ve alçakgönüllülük gibi erdemlerini vurguladığ1 gözlenmektedir. 1960'larda ve 1970'lerde araştırmacılar, çocuk kitaplarındaki cinsiyet klişelerini fark etmeye başlamışlardır. Cinsiyet farklılıklarını doğrulayan ilk araştırma 1972' de Weitzman tarafından yapılmıştır. Araştırmacı çocuk kitaplarında kadınların neredeyse görünmez olduğunu, erkeklerin lider olduğunu ve aktif rol oynadığını tespit etmiştir. Ayrıca, kadınların başlıklarda, merkezi rollerde ve ana karakterlerde yetersiz temsil edildiğini, erkeklerin meslek rollerinin kadınlardan daha yüksek bir statüye sahip olduğunu ve kadınları pasif ve hareketsiz olarak nitelendiren karakter farklılıklarını tespit etmiştir. Öte yandan, erkekler bağımsız ve aktif liderler olarak tanımlanmıştır (Narahara, 1998). Yapılan araştırmalar ardından 1987 yılında yapılan araştırmada kadın karakterlerin büyük çoğunluğunun kariyer hedeflerini ifade etmekte başarısız olduğu, kadın rol modellerinin eksik olduğu ve erkek karakterlerin bağımsız olduğu görülmüştür.

Sınıf ve okullar toplumun birincil sosyalleşme kurumları arasındadır. Bu yerlerde, çocuklar sosyal kimliklerini birbirlerine ve kurumlara göre anlamaya başlarlar. Her ne kadar okullar cinsiyetlerine göre farklılaştırılmış sosyal rolleri öğretmekten kesinlikle sorumlu olmasalar da genellikle kadınların alt düzey rollerini, müfredat seçimleri ile onları dışlayan veya klişeleştiren sınıf örgütleri aracılığıyla güçlendirirler. Bununla birlikte, okullar aynı zamanda cinsiyet, 1rk, etnik köken, dilin arka planı, yaş ve cinsellik temelindeki eşitsizliklerin, kimlik gruplarını daha eşit temsil eden yöntem ve materyaller seçerek potansiyel olarak değiştirilebileceği yerlerdir. Eğitim sürecinde, ders kitapları çocukların sosyalleşme sürecine yardımcı olacak en önemli araçlardan biridir (Freeman ve McElhinny, 1996: 242). Arıkan'a (2005) göre, okullar, öğretmenlerin, ders kitaplarının, sınıf materyallerinin, etkinliklerin ve belirli bir okul veya sınıfın tüm üyelerinin tutumlarının, bilgi temelli ve değer yüklü uygulamalarla öğrencilerin bilişsel ve duygusal oluşumlarına katkıda bulunduğu yerlerdir. Bunlar aracılığı ile öğrencilere sonsuz sayıda mesaj veya değer iletilir. Bu kapsamda bu materyaller ile öğrencilere olumsuz mesajların verilmesi tehlikeli sonuçlara neden olabilir. Öyleyse, bu değerler, kaçınılmaz olarak, toplumdaki barış ve dayanışmada erozyona neden olan, kaçınılmaz olarak, başkalarının nefret, hoşgörüsüzlük veya küçümseme gibi yanlış uygulamalara dayanarak öğrencilerin klişeleşmiş düşüncelerine dönüşebilir (Arıkan, 2005). Bu kapsamda cinsiyet ayrımı ya da toplumsal cinsiyet ile ilgili olumsuz mesaj içeren eğitim araçları toplumun geleceğini oluşturan öğrencilerin belirli kalıp yargılar ile yetişmesine neden olabilir.

Cumhuriyet'in ilk senelerinde yayınlanan ders kitaplarında aile içinde ve toplumda dayanışmayı artırmayı hedefleyen örnekler yer almaktadır. Örnek vermek gerekirse 1928 senesinde ilkokul 4. sınıflar için hazırlanan Yurt Bilgisi ders kitabında: "Bu annem, görüyorum ve fark ediyorum ki babamı hiçbir işte tek başına bırakmıyor, ona her konuda yardımcı oluyor. Annem ve babamla arasında sağlam bir tesanüt 
(dayanışma) var... Geçenlerde babam bana müşterek bir maksattan bahsetmişti. Bizim evimiz de ortak bir gaye ile teşkil edilmiş bir müessese olacak. Annem ve babam birleşmişler, çocuklarının ve kendilerinin saadetini temin etmek adına gayret ediyorlar... Baba ve anne galiba her evin temel taşı." (Refik, 1928). Görüldüğü üzere, Cumhuriyet'in ilk senelerinde erkek ve kadının ailesi ve evi için eşit sorumlulukları bulunmakta idi. Anne de baba da aile için eşit düzeyde önem arz etmektedir; çünkü ikisi de evin temel taşı şeklinde algılanmaktadır. Ancak 1950'lerden sonra hazırlanan ders kitaplarının (Dalsar, 1950; Kınal1, 1951; Çalapala, 1951; İrge, 1952; Kurtuluş, 1952; Kurtuluş, 1953) önemli bir kısmında "baba evin direğidir, mesut etmek ereğidir" şeklinde ifadeler yer almaktadır. Anne bütün şekillerde ütü yapan, çamaşır yıkayan, ev temizleyen, yemek yapan biri şeklinde gösterilmektedir. Yine aynı şekilde 1953 senesinde okutulan Yurttaşlık Bilgisi (Göçmen, 1953) ders kitabındaki, "Evde iş bölümü" adlı bölümde "Anne evde temizlik ve düzeni sağlar, yemek, dikiş işlerine bakar. Baba para kazanır." ifadeleri yer almaktadır (Helvacıŏ̆lu, 1996). Seçgin (2012), "Sosyal Bilgiler Dersinde Toplumsal Cinsiyet Etkinliklerinin Öğrencilerin Alg1 ve Tutumlarına Etkisi" adlı çalışmasında sosyal bilgiler dersinde toplumsal cinsiyet etkinliklerinin öğrencilerin alg1 ve tutumlarına etkisini araştırmıştır. Araştırmacı çalışmanın neticesinde; "toplumsal cinsiyet etkinliklerinin öğrencilerin toplumsal cinsiyete ilişkin algılarını somutlaştırdığı ve onlara farkındalık kazandırdığı, toplumsal cinsiyet etkinlikleri yaşam örneklerini doğrudan sunduğu için öğrenciler üzerinde etkili olduğu, cinsiyet eşitliği bakımından duyarlılık kazandırdığı ve eğitim sürecini zevkli bir hâle getirdiği" sonucuna ulaşmıştır. Gümüşoğlu, ders kitaplarında toplumsal cinsiyet konusunda çalışmalar veren araştırmacıların ilklerindendir. Gümüşoğlu'nun (1996) ders kitaplarında toplumsal cinsiyet temsilleri ile ilgili çalışması yurt içindeki ilk ve detaylı bir çalışma olma özelliğine sahiptir. Bu çalışmada Gümüşoğlu, ülkemizde 1928 ve 1995 yılları arasında okutulan çeşitli ders kitaplarını incelemiş ve kadın ve erkek cinsiyetlerinin nasıl yansıtıldığını ortaya koymuştur. Çalışma daha sonra Gümüşoğlu tarafından güncellenerek "Ders Kitaplarında Toplumsal Cinsiyet 1928'den Günümüze" adıyla tekrar basılmıştır. Gümüşoğlu (2016), günümüz ders kitaplarında toplumsal cinsiyet yaklaşımının 1950 yıllarından daha olumsuz olduğunu vurgulamıştır.

Toplumsal cinsiyet kavramı, okullarda ve kitaplar üzerinde yapilan toplumsal cinsiyet ile ilgili çalışmalar incelendiğinde ders kitaplarının toplumsal cinsiyet açısından incelenmesi merak unsuru oluşturmuştur. Bu bağlamda 4. sınıf Sosyal Bilgiler ders kitabının toplumsal cinsiyet açısından incelenmesi çalışmanın konusunu oluşturmuştur.

\section{Araştırmanın Problemi Amacı ve Önemi}

Çalışmada ilkokul 4. sınıf Sosyal Bilgiler ders kitabının toplumsal cinsiyet açısından çeşitli değişkenlere göre değerlendirilmesi amaçlanmıştır. Söz konusu kitapların içeriğinde yer alan metin ve görsellerinin öğrencilere cinsiyet ifadeleri ve toplumsal cinsiyet rollerine ilişkin görüş edindirme konusundaki rolünün tespiti çalışmanın temel hedefleri arasındadır.

Okul eğitiminin en önemli araçları arasında gösterilen öğrenci ders kitaplarının, kişilerin çok sayıda toplumsal rollerinin yanında cinsiyet rollerini de elde etmelerinde önemli bir yere sahiptir. Gelecek adına toplumsal cinsiyet ayrımının 
ortadan kaldırılmasının en kolay yolu ön yargısız veya çok az ön yargısı olan küçük yaştaki öğrencilere bu konuda verilecek sağlıklı eğitimle sağlanabilmektedir. Okullarda okutulan kitapların toplumsal cinsiyet ayrımı içermemesi bunun başarılmasında önemli bir katkı sunmaktadır.

Çalışmanın temel problemlerini;

a) 2019-2020 eğitim öğretim yılında Millî Eğitim Bakanlığı (MEB) tarafından ders kitabı olarak kabul edilmiş ve dağıtımı yapılmış olan 4. sınıf Sosyal Bilgiler ders kitabı, toplumsal cinsiyet rollerinin sunumu konusunda bir duyarlılık ile mi hazırlanmıştır?

b) 4. sınıf Sosyal Bilgiler ders kitabındaki metin ve görsellerde kadın ve erkeklere biçilen roller toplumsal cinsiyet eşitliği doğrultusunda sunulmuş mudur?

$\mathrm{Bu}$ bağlamda söz konusu ders kitaplarının içerikleri incelenmiş; şu alt problemlere cevap aranmıştır:

İlkokul 4. sınıf Sosyal Bilgiler ders kitabındaki metin ve görsellerde;

1. Bireylerle özdeşleştirilen nesneler ve renkler toplumsal cinsiyet açısından değişkenlik göstermekte midir?

2. Bireylere çizilen davranış kalıpları ve aile içi roller toplumsal cinsiyet açısından değişkenlik göstermekte midir?

3. Bireylerin meslek seçimleri toplumsal cinsiyet açısından değişkenlik göstermekte midir?

4. Bireylerin kişisel uğraşı ve eylemleri toplumsal cinsiyet açısından değişkenlik göstermekte midir?

5. Dil içinde toplumsal cinsiyetin farklı değişkenlerine göre şekillenmiş olan kalıplaşmış ifadeler yer almakta mıdır?

Literatür incelendiğinde ders kitaplarının farklı açılardan incelendiği birçok çalışmaya rastlanılmıştır. Fakat ders kitaplarının toplumsal cinsiyet açısından incelendiği çalışmaların az sayıda olduğu gözlemlendi. (Hayat Bilgisi Ders kitaplarında toplumsal cinsiyet rolleri üzerine bir inceleme (Sarıtaş ve Şahin, 2019), İlk öğretim Türkçe ders kitaplarında ortaya çıkan toplumsal cinsiyet rolleri üzerine bir inceleme (K1lıç ve Bircan, 2011), İlkokul ve ortaokul din kültürü ve ahlak bilgisi kitapları görsellerinin toplumsal cinsiyet açısından incelenmesi (Y1ld1z, 2013), Ortaokul Türkçe ders kitapları görsellerinde toplumsal cinsiyet (Yaylı ve Kitiş Çınar, 2014), Ders kitaplarında toplumsal cinsiyet (Gümüşoğlu, 2008), Ortaokul Türkçe ders kitaplarında toplumsal cinsiyet (Çınar, 2013), Ders kitaplarında toplumsal cinsiyet ayrımı (Güneş, 2008) Ortaokul Türkçe ders kitaplarında cinsiyet ifadeleri ve toplumsal cinsiyet rolleri (Yeşil, 2014), CEDAW öncesi ve sonrası ortaokul Türkçe ders kitaplarında yer alan toplumsal cinsiyet eşitliği faktörünün değerlendirilmesidir (Kükrer ve Kıbrıs, 2017).) 4. Sinıf Sosyal Bilgiler ders kitabının toplumsal cinsiyet açısından incelenmemesi alandaki eksikliği gidereceği düşünülmektedir.

İlkokul 4. sınıf Sosyal Bilgiler derslerinde kullanılan kitabın toplumsal cinsiyet bağlamında incelendiği bu çalışma neticesinde elde edilen bulguların gelecek yıllarda kitapların hazırlanma aşamasında fikir sağlayacağı düşünülmektedir. Toplumsal cinsiyet rollerinin ilkokul düzeyinde okutulan ve içerik olarak hayatla iç içe olan sosyal bilgiler ve hayat bilgisi gibi iki önemli ders ve bu derslerde okutulan ders kitapları aracılığı ile yeni nesillere doğru aktarımının sağlanması oldukça önemlidir. $\mathrm{Bu}$ öneme binaen, gelecek nesillerin doğru yönlendirmelerle şekillenmesi adına 
çalışmamızın faydalı olması umulmaktadır. Çalışma, ilkokul ve 4. sınıf Sosyal Bilgiler ders kitabının toplumsal cinsiyet bakımından ne kadar hassas ve duyarlı davrandı̆̆ını belirlemek, bu konularda eksiklikler var ise bunları ortaya çıkarmak gibi amaçlara ulaştığı takdirde ileride ders kitabı yazacak kişilere ve onları uygulayacak öğretmenlere olumlu katkılarda sağlayabilecek bir kaynak oluşturması açısından da önemli bir çalışmadır.

\section{Yöntem}

$\mathrm{Bu}$ çalışmada nitel araştırma yöntemlerinden doküman incelemesi kullanılmıştır. Yıldırım ve Şimşek (2008) nitel araştırmayı, "gözlem, görüşme ve doküman analizi gibi nitel veri toplama tekniklerinin kullanıldığı, algıların ve olayların doğal ortamda gerçekçi ve bütüncül bir biçimde ortaya konmasına yönelik nitel bir sürecin izlendiği araştırma" olarak tanımlamışlardır. Doküman analizi hem basılı hem de elektronik ortamdaki bilgi ve belgelerin sistematik bir şekilde ele alınması olarak tanımlanabilir (Bowen, 2009).

\section{Çalışma Grubu}

Millî Eğitim Bakanlığ1 Talim ve Terbiye Kurulu tarafından 2019-2020 eğitim öğretim yılı içerisinde ilkokul 4. sınıflarda okutulması uygun görülen ve MEB tarafından dağıtımı yapılmış Sosyal Bilgiler ders kitabı doküman incelemesinde kullanılmıştır. Bu kitabın kimliği aşağıda verilmiştir:

- $\quad$ Tüysüz, S. (2018). İlkokul 4 Sosyal Bilgiler Ders Kitabı, Ankara: Tuna Matbaacılık San. ve Tic. Aş.

\section{Veri Toplama Aracı}

Çalışmada kullanılan veriler, 2019-2020 eğitim-öğretim yılı için Millî Eğitim Bakanlığı tarafından tavsiye edilen ve dağıtımı yapılan İlkokul 4. sınıf Sosyal Bilgiler ders kitabında yer alan metinler, etkinlikler ve görsel unsurlardan elde edilmiştir.

İnceleme kapsamındaki kitaplara ulaşım Millî Eğitim Bakanlığı Eğitim Bilişim Ağ1 örün sitesinden (http:/ / www.eba.gov.tr/) sağlanmıştır.

\section{Verilerin Analizi}

Çalışma boyunca taranan kaynaklardan elde edilen veriler içerik analizi (içerik çözümleme) yöntemiyle değerlendirilmiştir.

İçerik analizi, toplumsal ya da toplum bilimsel araştırmalarda kullanılan bir gözlem tekniği olup toplum bilimlerin hemen hemen her alanında kullanılmakla birlikte kitle iletişim araçlarının yaygınlaşması ile meydana çıkmış ve önem kazanmıştır (Aziz, 2010). İçerik analizinde sözlü, yazılı ve diğer materyallerin belirli kurallara dayalı olarak kodlaması yapılır ve bunlara uygun temalar elde edilir. Daha sonra veriler düzenlenmiş temalara göre kategoriler oluşturulur ve bu kategori ve temalar uygun şekilde sayısallaştırarak sunulur (Büyüköztürk, Çakmak, Akgün, Karadeniz ve Demirel, 2015).

2019-2020 eğitim öğretim yılında okutulan ilkokul 4. sınıf Sosyal Bilgiler ders kitabında yer alan metinler ve görsellerde yer alan toplumsal cinsiyet kodlamalarını tespit edebilmek amacıyla konuya ilişkin kategoriler tespit edilmiştir. Sosyal Bilgiler ders kitabı içerikleri bu kategorilere göre analiz edilmiştir. Bu kategoriler oluşturulurken ders kitabının içeriklerini toplumsal cinsiyet bağlamında ele alan 
makaleler ve tezler incelenmiş; bu çalışmaların yöntemleri karşılaştırmalı olarak ele alınmıştır. Bu inceleme sonucunda Saydam (2018) ve Arslan'ın (2000) kategorilerinden yola çıkılarak ders kitaplarında toplumsal cinsiyet rollerine ilişkin bulgular tespit edilmiştir:

1. Bireylerle Özdeşleştirilen Nesne ve Renklere Göre Toplumsal Cinsiyet

2. Bireylerin Davranış Kalıpları ve Aile İçi Rollerine Göre Toplumsal Cinsiyet

3. Bireylerin Meslek Seçimine Göre Toplumsal Cinsiyet

4. Bireylerin Uğraşı ve Eylemlerine Göre Toplumsal Cinsiyet

5. Dil İçinde Kalıplaşan İfadelerde Toplumsal Cinsiyet

Oluşturulan kategoriler dikkate alınarak inceleme kapsamında yer alan ders kitabının içerikleri, metinler ve görseller olarak iki ayrı başlıkta toplumsal cinsiyet kavramı açısından incelenmiştir. Yapılan inceleme sonucu toplumsal cinsiyet kavramı ile ilgili tespit edilen metin ve görseller gerekli açıklamalar yapılarak değerlendirilmiştir. Araştırmada analiz sonuçlarının güvenirliğini sağlamak için iki ayrı araştırma tarafından ayrı ayrı kodlamalar yapılarak kodlayıcılar arasındaki uyum düzeyi (Miles ve Huberman, 1994) hesaplanmıştır. Bu hesaplama sonucu araştırmamızın güvenirliği \%89 olarak saptanmıştır.

\section{Bulgular}

Sosyal Bilgiler kitabında yer alan metinler ve görsellerdeki toplumsal cinsiyet kodlamalarını tespit edebilmek amacıyla konuya ilişkin kategoriler tespit edilmiştir. $\mathrm{Bu}$ kategorilere göre aşağıdaki bulgulara ulaşılmıştır. Ayrıca kitaptan ilgili kategorileri açılamak için metin ve görsellere yer verilerek betimlemeler yapılmaya çalışılmıştır.

\section{Bireylerle Özdeşleştirilen Nesneye Göre Toplumsal Cinsiyet}

Tablo 1'e göre 4. sınıf Sosyal Bilgiler ders kitabındaki metin ve görsellerde toplam 97 nesneye ulaşılmıştır. Bunlardan kızlarla eşleştirilen nesne ve renk sayısı 33 iken erkeklerle eşleştirilen nesne ve renk sayısı 38'dir. Her iki cinsiyet ile eşleştirilen nesne ve renk sayısı ise $26^{\prime}$ dir.

Tablo 1

Nesneler ve Renkler-Sosyal Bilgiler 4 (Tuna Matbaacilı)

\begin{tabular}{lcc}
\hline Nesneler ve Renkler & Örnek Sayısı & $\mathbf{0}$ \\
\hline Kızlarla eşleştirilen nesne ve renk sayısı & 33 & 34 \\
\hline Erkeklerle eşleştirilen nesne ve renk sayısı & 38 & 39,2 \\
\hline Her iki cinsiyet ile eşleştirilen nesne ve renk sayısı & 26 & 26,8 \\
\hline Toplam nesne ve renk sayısı & 97 & 100 \\
\hline
\end{tabular}

Tablo 1 incelendiğinde ders kitabında kızlarla eşleştirilen nesne ve renkler; pembe ve açık tonlu renkler (14), sevimli hayvanlar (6), bebek (4), mutfak gereçleri (3), toka (4), saç kurutma makinesi (1), elektrikli süpürge (1) iken erkeklerle eşleştirilen nesne ve renkler ise bisiklet (6), top (8), araba (5), bilgisayar (2), mavi ve koyu tonlu renkler (17)' dir. Her iki cinsiyetle eşleştirilen nesne ve renkler ise yeşil, kırmızı, sarı, mor renkleri (12), telefon (5), diş fırçası (2), okul çantası (5), gözlük (2)'tür. 
Örnek 1: "Seda, Sıla ve Selçuk üç kardeştir. Babalarından Seda gitar, Sıla ayakkabı, Selçuk ise uzaktan kumandalı bir araba almasın istemektedir. Ancak ailenin bütçesi çocuklardan yalnızca birinin isteğini karşılayabilecek durumdadır." (Tüysüz, 2019: 123). Paragrafta adı geçen erkek çocuğu uzaktan kumandalı araba istemektedir.

\section{Örnek 2:}

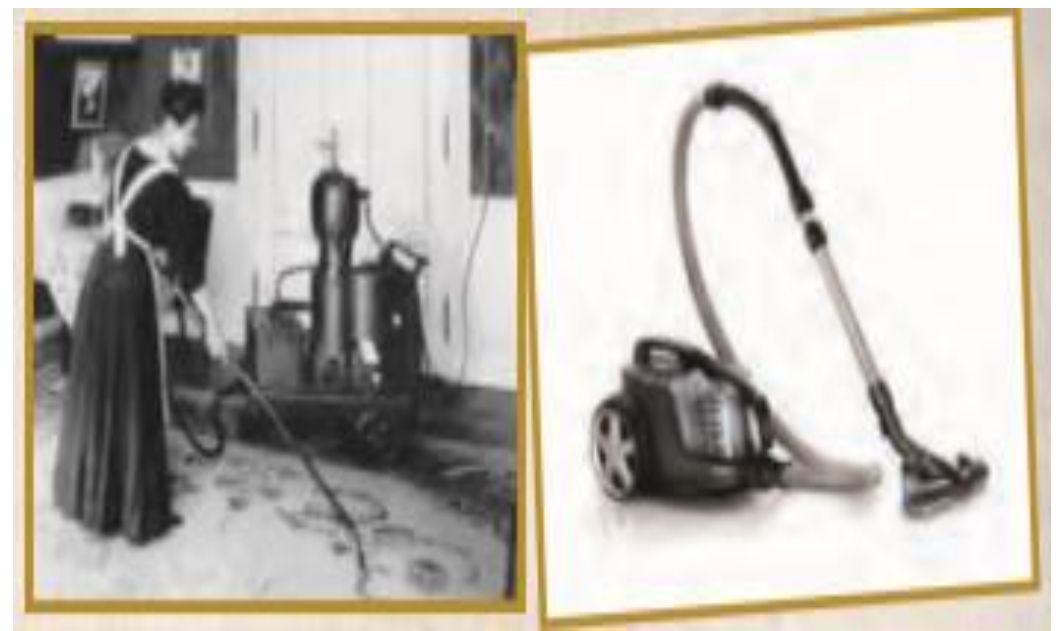

Şekil 1. Elektrik Süpürgesi Örneği (Kaynak: Sosyal Bilgiler 4 (Tuna Matbaacılık) Tüysüz, 2019: 100).

Şekilde elektrikli süpürgeyi kullanan kişi kadındır (Şekil 1.).

\section{Örnek 3:}

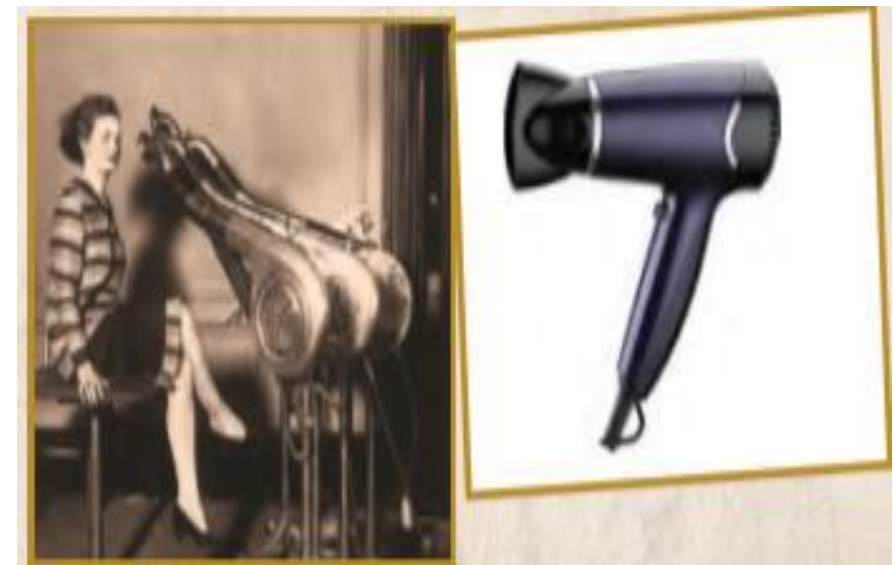

Şekil 2. Saç Kurutma Makinesi Örneği (Kaynak: Sosyal Bilgiler 4 (Tuna Matbaacılı) Tüysüz, 2019: 100).

Saç kurutma makinesi kadınlarla özdeşleştirilen bir nesnedir (Şekil 2.).

Örnek 4: "Evimizin yatak odasında annemin çeyiz sandı̆̆ı duruyor. Ceviz ă̆acından yapılmış, üzeri oymalarla süslenmiş bu sandığa annem çok önem verir. Ona bunun nedenini sorduğumda bana şunları anlattı:" (Tüysüz, 2019: 39).

Çeyiz sandı̆̆ hazırlamak yani evlenmeden evvel bir evde kullanılan tekstil ürünlerini hazır hale getirmek kadınlara has bir özellik olarak görülmektedir. 


\section{Örnek 5:}

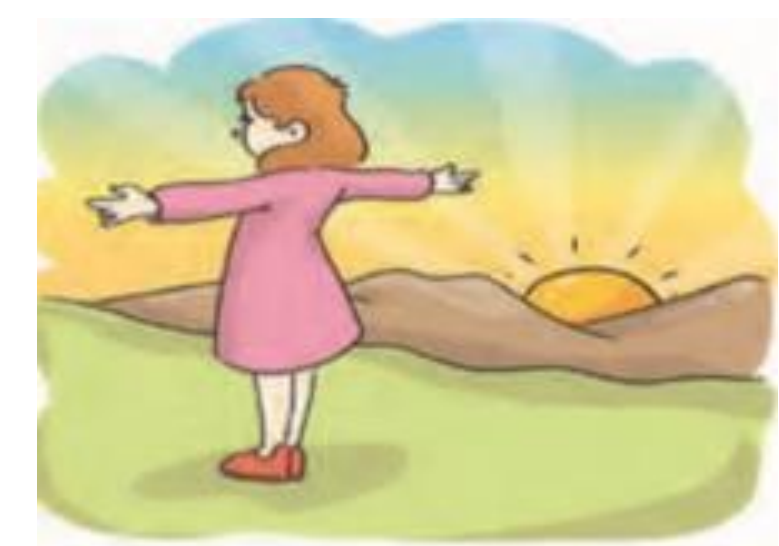

Şekil 3. Renk Seçimi Örneği (Kaynak: Sosyal Bilgiler 4 (Tuna Matbaacılık) Tüysüz, 2019: 63).

Şekilde kız çocuğunun pembe kıyafet giymesi toplumsal cinsiyet açısından dikkat çekicidir (Şekil 3.).

Örnek 6: "Önceki uygulamada ülkemizde erkeklere mavi, kadınlara pembe renkli nüfus cüzdan veriliyordu. Örneğin benim nüfus cüzdanımın rengi pembe, ağabeyiminki ise maviydi. Yeni uygulamada renk ayrımı yapılmadan kadın erkek bütün Türk vatandaşlarn turkuaz renkli kimlik kartlarmı kullanacak. Vatandaşların cinsiyet bilgileri bundan böyle kimlik kartındaki cinsiyet bölümüne erkekler için E, kadınlar için K yazılarak belirtilecek." (Tüysüz, 2019: 14).

4. sinıf Sosyal Bilgiler ders kitabında yer alan "Birey ve Toplum" adlı ünitede yer alan "Herkesin Bir Kimliği Var" adlı metinde Türkiye Cumhuriyeti kimlik kartı tanıtılmaktadır. Tanıtım yapılırken nüfus cüzdanı ile ilgili olarak yukarıda yer alan metinde kimlik kartlarının eskiden bireylerin cinsiyetine göre renklendirildiği yeni uygulamada ise her iki cinsiyet için de aynı renkler kullanıldığı ifade edilmektedir. Bahsi geçen bu uygulamada da olduğu gibi, toplumsal cinsiyet kendisini sadece beklentiler vasıtasıyla değil, etkinlik ve nesneler aracılığıyla da yansıtır. Cinsiyetinin belli olması ile birlikte bebeğe "cinsiyetine uygun" oyuncak ve renk seçimi buna örnektir. Eski uygulamada nüfus cüzdanlarının toplumun cinsiyetlere bakış açısına göre renklendirilmesi de tam olarak bu konu ile ilgilidir.

4. sınıf Sosyal Bilgiler ders kitabında yukarıdaki örneklerin yanı sıra kız çocukları ve kadınların taç, toka, oyuncak bebek, sevimli hayvanlar, mutfak gereçleri gibi nesnelerle aynı karede yer aldıkları; erkeklerin ise top, bisiklet, bilgisayar gibi nesnelerle bir arada bulundukları tespit edilmiştir. Bununla birlikte kitapta erkeklerin genellikle mavi tonlarında veya koyu renkli tonlardaki eşyalarla ön palan çıktıkları, kız çocukları ve kadınların ise pembe başta olmak üzere açık ve canlı tonlu renklerle bütünleştirildikleri; kırmızı, yeşil, sarı ve beyaz gibi renklerin de her iki cinsiyet için de ortak olarak kullanıldıkları görülmüsstür.

\section{Bireylerin Davranış Kalıpları ve Aile İçi Rollerine Göre Toplumsal Cinsiyet}

Tablo 2'ye göre 4. sınıf Sosyal Bilgiler ders kitabındaki metin ve görsellerde toplam 35 davranış kalıbı ve aile içi rol öğesine ulaşılmıştır. Bunlardan kızlarla eşleştirilen davranış kalıbı ve aile içi rol sayısı 29 iken erkeklerle eşleştirilenlerin sayısı 19'dur. Her iki cinsiyet ile eşleştirilen davranış kalıbı ve aile içi rol sayısı ise 83'tür. 
Tablo 2

Davranış Kalıbı ve Aile İçi Rol- Sosyal Bilgiler 4 (Tuna Matbaacılık)

\begin{tabular}{lcc}
\hline Davranış Kalıbı ve Aile İçi Roller & Örnek Sayısı & \% \\
\hline Kızlarla eşleştirilen davranış kalıbı ve aile içi rol sayısı & 35 & 42,2 \\
\hline Erkeklerle eşleştirilen davranış kalıbı ve aile içi rol sayısı & 29 & 34,9 \\
\hline Her iki cinsiyet ile eşleştirilen davranış kalıbı ve aile içi rol sayısı & 19 & 22,9 \\
\hline Toplam davranış kalıbı ve aile içi rol sayısı & 83 & 100 \\
\hline
\end{tabular}

Tablo 2 incelendiğinde ders kitabında kızlarla eşleştirilen davranış kalıpları ve aile içi roller; ev işlerine yardım etmek (12), alışveriş yapmak (9), düzenli olmak (8), çalışkan olmak (2), çocuk bakmak (4) iken erkeklerle eşleştirilen davranış kalıpları ve aile içi roller ise evin geçimini sağlamak (12), tamir işleri işleriyle uğraşmak (8), düzenli olmamak (4), araba sürmek (5) 'tir. Her iki cinsiyetle eşleştirilen davranış kalıpları ve aile içi roller ise öğrencilik (10), oyun oynamak (9)'tır.

\section{Örnek 1:}

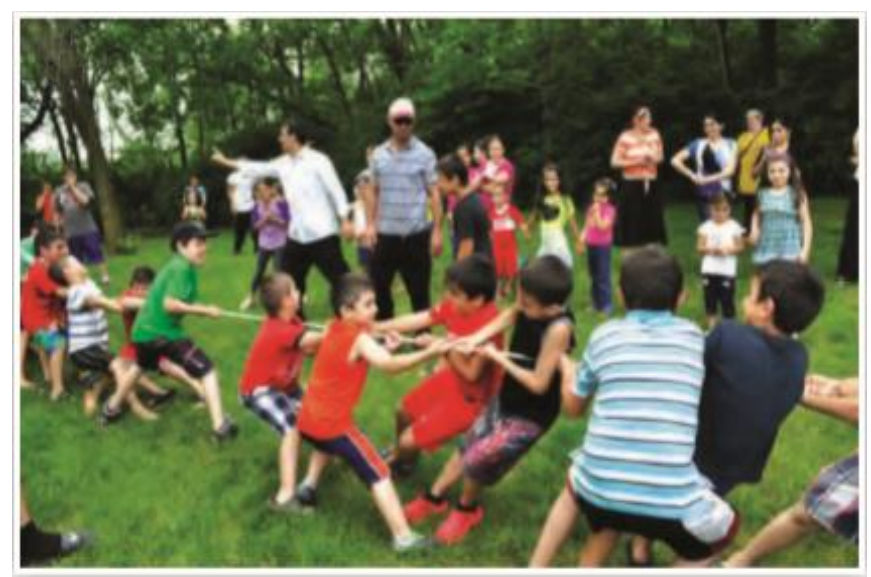

Şekil 4. Halat Çekme Örneği (Kaynak: Sosyal Bilgiler 4 (Tuna Matbaacılık) Tüysüz, 2019: 124).

Halat çekme, güç gerektiren bir eylem olduğu için erkeklerle örneklendirilmiştir. Buradan kas gücü gerektiren eylemlerin erkekler tarafından yapılabileceği yargısına ulaşılmaktadır (Şekil 4.). 


\section{Örnek 2:}

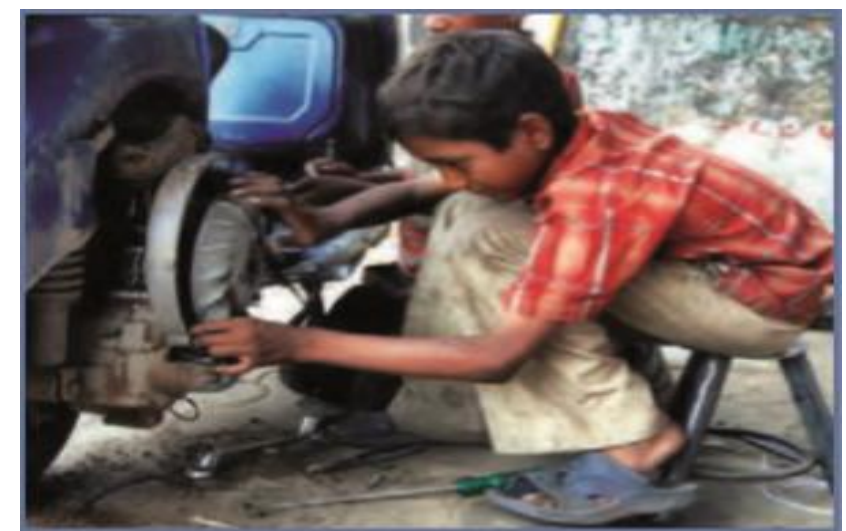

Şekil 5. Tamir İşleri Örneği (Sosyal Bilgiler 4 (Tuna Matbaacılık) Tüysüz, 2019: 132).

Şekilde otomobili tamir etmeye çalışan kişinin bir erkek çocuğu olduğu görülmektedir (Şekil 5.).

Bireylerin davranış kalıpları ve aile içi rollerine göre toplumsal cinsiyet kategorisinde çalışmamızın kapsamında incelediğimiz ders kitaplarında yer alan görseller ve metinlerde kadın ve erkek cinsiyetlerinin davranış kalıpları sergiledikleri ve aile için hangi rolleri üstlendiklerine bakılmıştır. Bu amaçlara göre çalışma kapsamında yer alan ders kitabı için şu değerlendirmeleri yapmak mümkündür:

İncelenen ders kitabında toplumsal cinsiyet konusunu ilgilendiren örnekler kadınlar ve kız çocukları için ev işleri, çocuk bakımı görsellerde görülmüştür. Genel olarak erkeler daha ağır davranış kalıpları sergilerken kadınlar daha naif davranışlar sergilemektedir. Bununla birlikte erkeklerin her zaman eve para getiren kişi rolünde olduğu gözlemlenmiştir.

\section{Bireylerin Meslek Seçimine Göre Toplumsal Cinsiyet}

Tablo 3'e göre 4. Sosyal Bilgiler ders kitabındaki metin ve görsellerde toplam 100 meslek öğesine ulaşılmıştır. Bunlardan kızlarla eşleştirilen meslek sayısı 25 iken erkeklerle eşleştirilenlerin sayısı 35'tir. Her iki cinsiyet ile ilişkilendirilen meslek sayısı ise 40 tır.

Tablo 3

Meslek Seçimi-Sosyal Bilgiler 4 (Tuna Matbaacılık)

\begin{tabular}{lcc}
\hline Meslek Seçimi & Örnek Sayısı & $\mathbf{\%}$ \\
\hline Kızlarla eşleştirilen meslek sayısı & 25 & 25 \\
\hline Erkeklerle eşleştirilen meslek sayısı & 35 & 35 \\
\hline Her iki cinsiyet ile eşleştirilen meslek sayısı & 40 & 40 \\
\hline Toplam meslek sayısı & 100 & 100 \\
\hline
\end{tabular}

Tablo 3 incelendiğinde ders kitabında kızlarla eşleştirilen meslekler; öğretmenlik (13), hemşirelik (10), tekstil işçiliği (2), iken erkeklerle eşleştirilen 
meslekler ise şoförlük (8), otomotiv sektörü (2), polislik (8), mühendislik (6), balıkçılık (2), çiftçilik (2), madencilik (4), ormancılık (3) 'tır. Her iki cinsiyetle eşleştirilen meslekler ise doktorluk (9), dişçilik (8), memurluk (23)'tur.

\section{Örnek 1:}

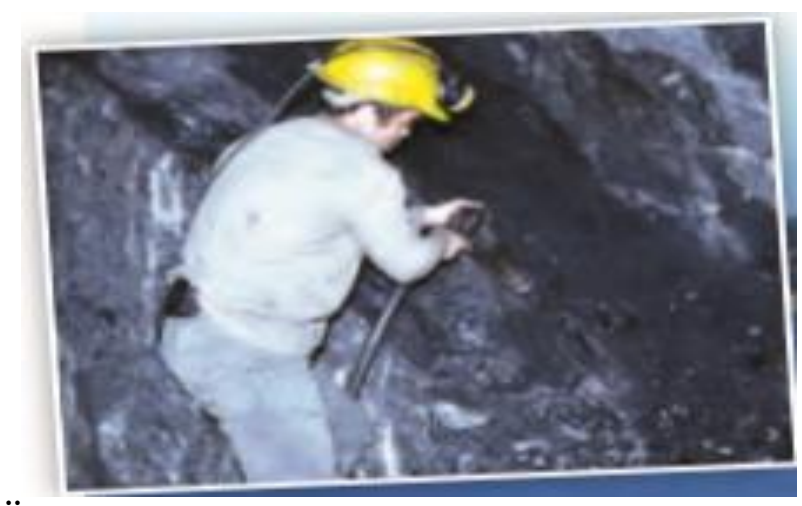

Şekil 6. Madenci Örneği (Kaynak: Sosyal Bilgiler 4 (Tuna Matbaacılık) Tüysüz, 2019: 127).

"Benim babam ilimiz stnırlar içindeki bir taş kömürü ocağında maden mühendisi olarak çalışıyor. Maden mühendisleri yer altında ve yer üstünde bulunan madenlerin işletilmeye elverişli olup olmadığına karar verirler. Bunun yanı stra madenlerin en ucuz ve en verimli şekilde çıkarılması işlemlerini planlayıp bunlara gözcülük ederler." (Tüysüz, 2019: 127).

Görselde ve paragrafta bahsi geçen baba maden mühendisidir. Bu mesleğin bir erkek tarafından icra ediliyor olarak gösterilmesi toplumsal cinsiyeti ilgilendiren bir durumdur (Şekil 6.).

\section{Örnek 2:}

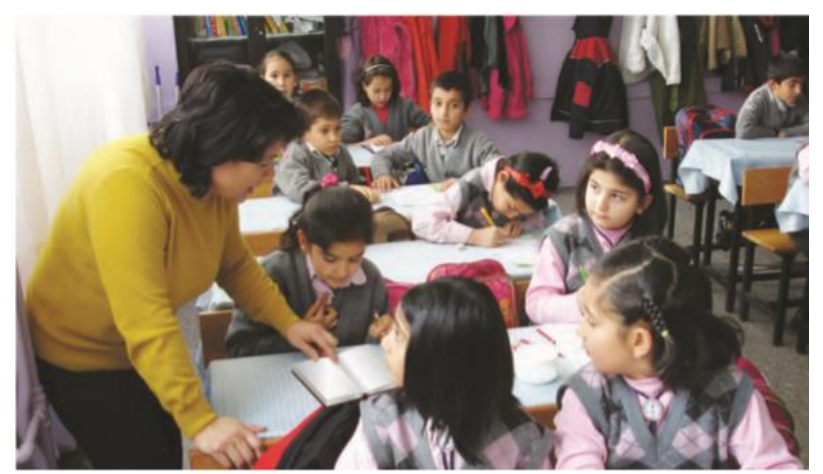

Şekil 7. Öğretmen Örneği (Kaynak: Sosyal Bilgiler 4 (Tuna Matbaacılık) Tüysüz, 2019: 130).

4. sınıf Sosyal Bilgiler ders kitabında yer alan "Birey ve Toplum" adlı ünitede kullanılan görselde bir sınıf ortamı görülmektedir (Şekil 7.). Öğretmen ve öğrencilerin yer aldığı görselde öğretmenin kadın olması toplumsal cinsiyet açısından incelendiğinde dikkat çekmektedir. Zira yerleşik hayata geçişten bu yana, kadının çocukla ve ev içi işlerle ilişkilendirilmesi, tarihî süreç içerisinde bazı değişimlerle kadının çalışmamasına ya da ev yaşamıyla uyumlu işler tercih etmesine yönelik anlayışı geliştirmiştir. Ev ve çocukla ilişkili olması açısından, okul öncesi veya ilkokul öğretmenliğinin kadınlara uygun olduğu algısı bu anlayışın mahsulüdür. 
Örnek 3:
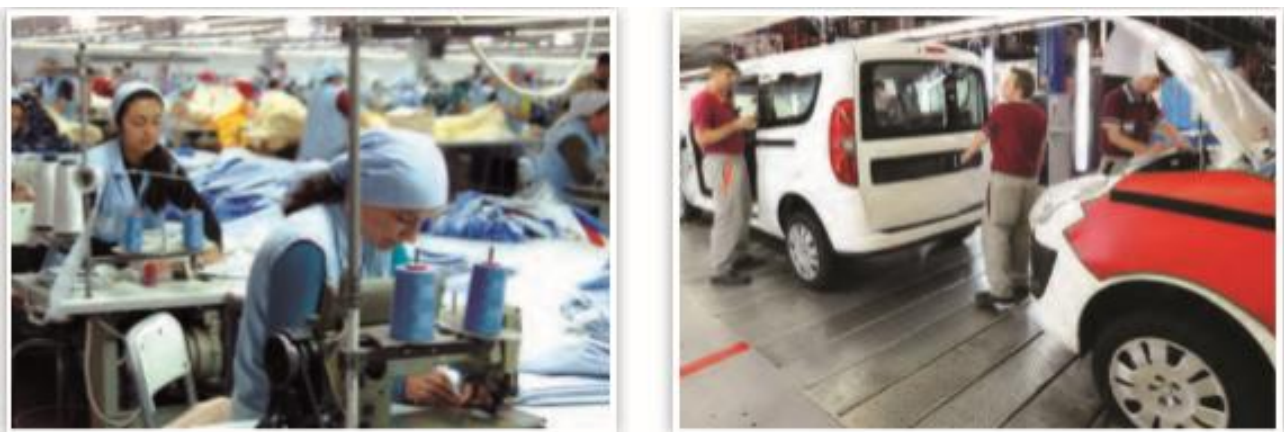

Şekil 8. Tekstil-Otomotiv Örneği (Kaynak: Sosyal Bilgiler 4 (Tuna Matbaacılık) Tüysüz, 2019: 130).

Görselin bir tarafında yer alan tekstil firmasında çalışan kadın işçiler, diğer tarafında ise otomotiv sektöründe çalışan erkek işçiler cinsiyetleri ile anılan mesleklerden birini temsil etmektedirler (Şekil 8.).

Bireylerin meslek seçimine göre toplumsal cinsiyet kategorisinde çalışma kapsamında incelenen ders kitaplarında yer alan görseller ve metinlerde kadın ve erkek cinsiyetlerinin hangi meslekler ile eşleştirerek sunulduğu incelenmiştir. Burada her iki cinsiyet için kitaplarda sunulan meslek çeşitlerinin birbirinden belirgin bir şekilde farklılık gösterip göstermediğine bakılmıştır. Bu amaçlara göre çalışma kapsamında yer alan ders kitapları için şu değerlendirmeleri yapmak mümkündür:

İncelenen kitapta metin ve görsellerde rastladığımız hemşireler ve öğretmenlerin daha çok kadın olduğu; madencilik, balıkçılık, ormancılık, emniyet ve güvenlik güçleri (polis, asker, güvenlik görevlisi), servis şoförlüğü gibi işlerin tamamının erkek olduğu; yöneticilik, doktorluk gibi işlerin de her iki cinsiyet için de yaklaşık bir dağılım gösterdiği tespit edilmiştir.

\section{Bireylerin Uğraşı ve Eylemlerine Göre Toplumsal Cinsiyet}

Tablo 4'e göre 4. sinıf Sosyal Bilgiler ders kitabındaki metin ve görsellerde toplam 60 uğraşı ve eylem öğesine ulaşılmıştır. Bunlardan kızlarla eşleştirilen uğraşı ve eylem sayısı 17 iken erkeklerle eşleştirilenlerin sayısı 12' dir. Her iki cinsiyet ile eşleştirilen uğraşı ve eylem sayısı ise $31^{\prime}$ dir.

Tablo 4

Uğraşı ve Eylem-Sosyal Bilgiler 4 (Tuna Matbaacılık)

\begin{tabular}{lcc}
\hline Uğraşı ve Eylemler & Örnek Sayısı & $\mathbf{0}$ \\
\hline Kızlarla eşleştirilen uğraşı ve eylem sayısı & 17 & 28,3 \\
\hline Erkeklerle eşleştirilen uğraşı ve eylem sayısı & 12 & 20 \\
\hline Her iki cinsiyet ile eşleştirilen uğraşı ve eylem sayısı & 31 & 51,7 \\
\hline Toplam uğraşı ve eylem sayısı & 60 & 100 \\
\hline
\end{tabular}

İncelenen ders kitabında kızlarla eşleştirilen uğraşı ve eylemler; ip atlamak (8), şarkı söylemek (4), piyano çalmak (1), müzik dinlemek (2), çiçek toplamak (2) iken 
erkeklerle eşleştirilen uğraşı ve eylemler ise top (futbol, basketbol) oynamak (5), misket oynamak (1), gitar çalmak (1), satranç ve zihni geliştirici oyunlar oynamak (1), bilgisayar oynamak (1), araştırma yapmak (1), bisiklet sürmek (2)'tir. Her iki cinsiyetle eşleştirilen uğraşı ve eylemler ise kovalamaca oynamak (13), saklambaç oynamak (18) 'tır.

\section{Örnek 1:}

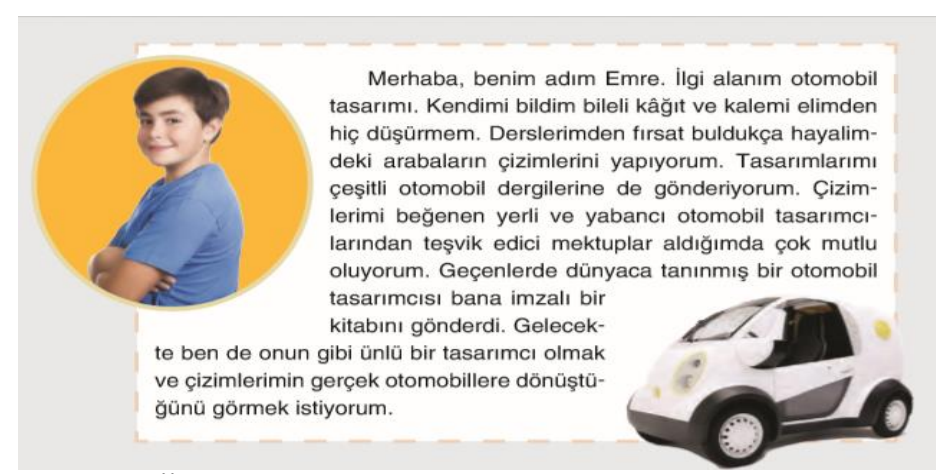

Şekil 9. Otomobil Örneği (Kaynak: Sosyal Bilgiler 4 (Tuna Matbaacılık) Tüysüz, 2019: 19).

Örnekte Emre adlı erkek çocuğun otomobil tasarımına ilgi duyduğu ifade edilmektedir. Bu durum tam olarak ilgi ve uğraşlar konusunda toplumun bireyleri cinsiyetlerine göre yönlendirmesine ve de kabul etmesine örnektir (Şekil 9).

\section{Örnek 2:}
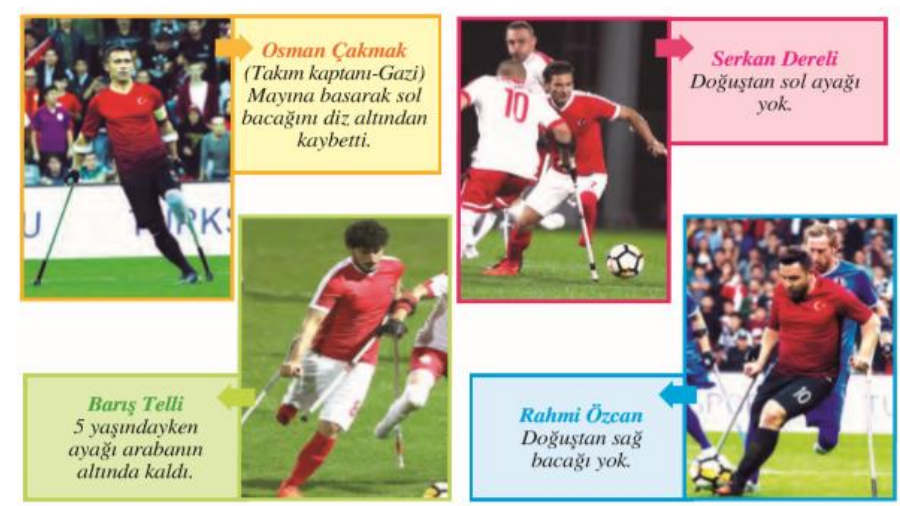

Şekil 10. Futbol Örneği (Kaynak: Sosyal Bilgiler 4 (Tuna Matbaacılık) Tüysüz, 2019: 29).

$\mathrm{Bu}$ şekil toplumsal cinsiyetin farklı değişkenleri açısından incelendiğinde futbol oynayan tüm bireylerin erkek olduğu dikkati çekmektedir. Oysa futbola ilgi duyan hatta fiziksel engeli olmasına rağmen bu alanda gayret gösteren pek çok kadın ya da kız çocuğuna rastlamak mümkündür (Şekil 10). 


\section{Örnek 3:}

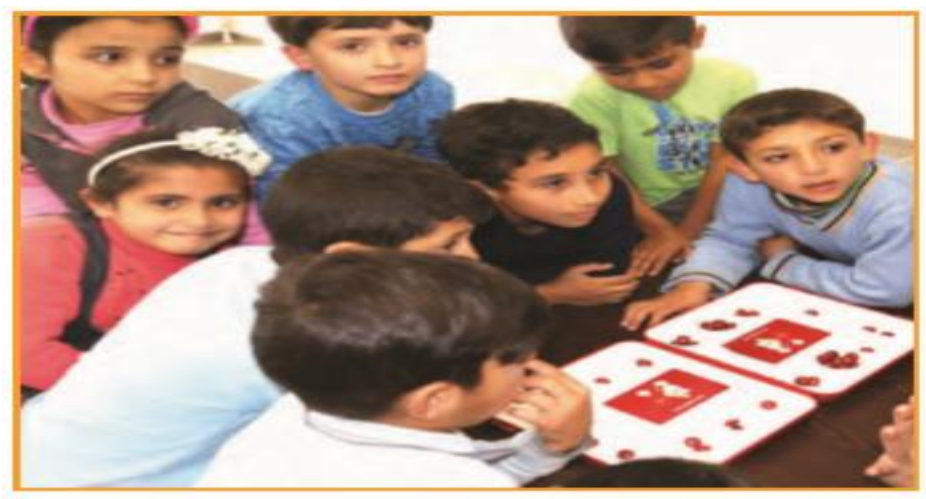

Şekil 11. Mangala Örneği (Kaynak: Sosyal Bilgiler 4 (Tuna Matbaacılık) Tüysüz, 2019: 26).

Bu görselde dikkati çeken ise cinsiyetlerin temsil ettikleri uğraşı ve eylemlerdir. Zira burada mangala gibi zihinsel becerileri gerektiren bir oyununu sadece erkek çocukları oynamaktadır. Birçok toplumda olduğu gibi toplumumuzda da karmaşık işlemleri çözme, matematik ve mantık becerilerine sahip olma gibi özellikler erkeklerle bağdaştırılmaktadır. Kız çocukları veya kadınlar ise toplum tarafından daha zarif ve nazik uğraşı ve eylemlere yönlendirilmekte ya da bu tip eylemlerle özdeşleştirilmektedir (Şekil 11).

\section{Örnek 4:}

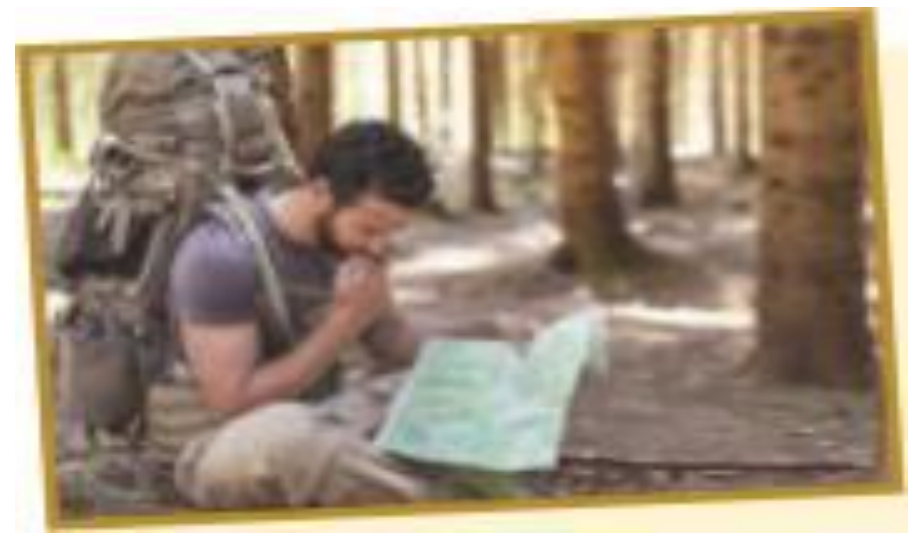

Şekil 12. Gezgin Örneği (Kaynak: Sosyal Bilgiler 4 (Tuna Matbaacılık) Tüysüz, 2019: 102).

Gezginlik birçok toplumda erkeklerle özdeşleştirilmektedir (Şekil 12).

Örnek 5: “Ampulün icadına yönelik ilk çalışmalar 1802 yılında İngiliz Humprey Davy (Hampri Devi) başlattı"...."1840 yılında Warren de la Rue (Varnn dö la Ru), Davy'nin bu yöntemini geliştirdi"..."Lambanın gelişimine katkıda bulunmuş en önemli isim Thomas Edison (Tamıs Edison) oldu"..."1901'de Peter Hewitt (Pitır Hevit) floresan lambalarm başlangıcı olan mavimsi beyaz ışık yayan cıvalı buhar lambasını icat etti" (Tüysüz, 2019: 104105).

...."Bir teknoloji ürünü olarak ilk mesaj iletme makinesi 1793'te Fransız Claude Chappe (Kuloud Şape) tarafindan icat edildi... Işaretle haberleşme sistemi 1840'lardan 
itibaren yerini Amerikalı mucit Samuel Morse'un (Samuel Mors) elektrikli telgrafina bıraktı"... "Amerikalı mucit Alexander Graham Bell (Aleksandır Gıraham Bel) elektrik akımının ses titreşimlerinin etkisiyle değiştiŏini keşfetti...radyonun da mucidi olan İtalyan bilim insanı Marconi (Markoni) 19. yüzyılın sonlarnna doğru telsiz denilen haberleşme cihazını icat etti. 1973 yılında Martin Cooper (Martin Kupır) telsiz teknolojisini geliştirerek cep telefonuna dönüştürdü." (Tüysüz, 2019: 106-107).

Yukarıda verilen örnek incelendiğinde icatlar konusunda bahsi geçen ve insanoğlu için çok önemli nesneleri icat eden mucitlerin tamamının erkek olduğu görülmektedir. 4. Sınıf Sosyal Bilgiler ders kitabında yer alan görsel ve metinlerde otomobil tasarımı, futbol, mangala gibi oyunların yanı sıra gezgin ve mucit örneklerinin erkeklerden seçildiği göze çarpmaktadır.

\section{Dil İçinde Kalıplaşan İfadelerde Toplumsal Cinsiyet}

Tablo 5'e göre 4. Sınıf Sosyal bilgiler ders kitabındaki metin ve görsellerde toplumsal cinsiyet ile ilgili toplam 10 adet dil içi kalıplaşmış ifadeye ulaşılmıştır. Bunlardan kızlarla eşleştirilen dil içi kalıplaşmış ifade sayısı 6 iken erkeklerle eşleştirilenlerin sayısı $4^{\prime}$ tür.

Tablo 5

Dil İçinde Kalıplaşmış Iffadelerde Sosyal Bilgiler 4 (Tuna Matbaacılık)

\begin{tabular}{lcc}
\hline Dil İçinde Kalıplaşmış Ífadeler & Örnek Sayısı & $\mathbf{0}$ \\
\hline Kızlarla eşleştirilen dil içinde kalıplaşmış ifade sayısı & 6 & 60 \\
\hline Erkeklerle eşleştirilen dil içinde kalıplaşmış ifade sayısı & 4 & 40 \\
\hline Her iki cinsiyet ile eşleştirilen dil içinde kalıplaşmış ifade sayısı & 0 & 0 \\
\hline Toplam dil içinde kalıplaşmış ifade sayısı & 10 & 100 \\
\hline
\end{tabular}

Tablo 5 incelendiğinde ders kitabında erkekleri pozitif olarak ayırt eden 4 (iş adamı, şehit oğlu, insan oğlu) örneğe, kadınları ikinci plana atan veya onları analık vasfını "önemli" manasında dil içinde olumlu anlamda vurgulayan 6 (ana ..., kız isteme) örneğe rastlanmıştır.

Örnek 1: "Kardeşim doğduktan bir süre sonra 2014 yılının eylül ayında anaokuluna başladım. Altıncı yaş günümü anaokulunda arkadaşlarımla birlikte kutladım. Bu, evimiz dışında kutladığım ilk yaş günüydü." (Tüysüz, 2019: 17).

Okul öncesi çocuklarının gittiği okulu ifade etmek amacıyla kullanılan "Anaokulu" kelimesi cinsiyet ayrımcılığı içermektedir.

Örnek 2: "Türk iş adamlan, bă̆ımsızlı̆̆ını kazandı̆̆ı ilk günlerden itibaren Türkmenistan'ın kalkınmasına katkı să̆lamaktadır..." (Tüysüz, 2019: 184).

İş adamı kelimesi cinsiyet ayrımcılığı içermektedir.

Örnek 3: "Elektrikten üretilen ışığın hayatımızda önemli bir yeri vardır. Bugün insanoğlu geceleyin de gezebiliyor, rahatça kitap okuyabiliyor, spor yapabiliyorsa bunu harika bir aydınlatma aracı olan elektrik ampulüne borçludur." (Tüysüz, 2019: 104).

Kuşlar gibi uçabilmek, insanoğlunun tarih boyunca en büyük özlemlerinden biri olmuştur." (Tüysüz, 2019: 104). 
Örnek 4: "Sen şehit oğlusun, incitme, yazıktır, atanı"

İstiklal Marşımızda geçen "şehit oğlu" ifadesi, şekil olarak erkekleri ifade etmektedir. Bu sebeple de ayrımcılık içermektedir.

Örnek 5: "Müzedeki bir diğer bölüm Etnografik Eserler Salonu'dur. Burada kız isteme sahnesi, kına gecesi, çalgıcılar ve kına töreninde ikram edilen bulgur aşının hazırlanışı mankenlerle canlandırılmıştır." (Tüysüz, 2019: 40).

Kız istemek, kız almak, kız vermek gibi kalıplaşmış ifadeler ayrımcılık içeren ifadelerdir.

Örnek 6: "Zavallı karısı ise kocasının kendilerine yetişmekte olduğunu görünce kızını sarp kayalardan aşağı atarak kaçmaya devam etmiş." (Tüysüz, 2019: 81).

Paragrafta geçen zavallı ifadesi bir kadın için kullanılmış olup ayrımcı bir anlam içermektedir.

4. sınıf Sosyal Bilgiler ders kitabındaki metin ve görsellerde kadın ve erkeler için kullanılan hitap sözcüklerinden ve akrabalık ilişkilerini belirten sözcüklerin yanı sıra Anadolu, hanım, bacı gibi dil içi kalıplaşmış ifadelere rastlanmıştır.

Dil içinde kalıplaşan ifadelerde toplumsal cinsiyet kategorisinde çalışmanın kapsamında incelenen ders kitabında yer alan görseller ve metinlerde kadın ve erkek cinsiyetlerine yönelik ayrımcı bir tutumun dile yansıyıp yansımadı̆̆ $\mathrm{Bu}$ amaçlara göre çalışma kapsamında yer alan ders kitapları için şu değerlendirmeleri yapmak mümkündür:

İncelenen kitabının genelinde istisnai örnekler dışında yazı diline yansıyan cinsiyetlere yönelik ayrımcı bir tutuma rastlanmamıştır. Kitapların genelinde "ana" sözcüğü yazı diline yansıyan cinsiyetlere yönelik ayrımcı bir ifade olarak tespit edilmiştir. Bunların yanı sıra kız isteme, insanoğlu bilim, adamı, adam etmek vb. gibi erkeklere yönelik pozitif cinsiyet ayrımcılı̆̆ı içeren bazı örneklere rastlanmıştır.

\section{Tartışma, Sonuç ve Öneriler}

İncelenen ders kitabında da kız çocukları mutfak eşyaları ve bebek gibi oyuncaklar ile erkek çocuklar ise uçak, araba, silah gibi idare ve güç sembolleri içeren oyuncaklarla birlikte görülmektedir. Tolan yaptığı çalışmada kız çocuklarının kimliklerinin gelenekçi bir yapı içerisinde toplumsallaşmasını sağlayan en önemli unsurlardan biri oyuncak ve oyundur. Kız çocukları çok küçük yaşlardan itibaren küçük mutfak eşyaları ve bebek gibi oyuncaklar ile ev içi rollere alıştırılırken, erkek çocuklar ise uçak, araba, silah gibi idare ve güç sembolleri içeren oyuncaklara yönlendirilir (Tolan, 1991). Çocuk oyuncakları medyada, oyuncak marketlerinde, kitap içeriklerinde vb. alanlarda hep belirli bir sınıflandırma içinde vurgulanmaktadır. Çocuklar üzerinde yapılan araştırmalarda sıklıkla çocukların toplumsal cinsiyete göre değişmeyen oyuncaklarla yani erkek çocukların erkek oyuncaklarıyla, kız çocukların kız oyuncaklarıyla oynadıkları görülmektedir (Giddens, 2000). Gürşimşek ve Günay (2005) yaptıkları araştırmada kadınların tercih ettikleri aksesuarların eşarp, fular, kolye, küpe ve taç olduğu sonucuna ulaşmışlardır. Erkeklerin ise aksesuarlarının arasında bu çalışma ile benzer olarak şapka ve gözlük de yer almaktadır. Literatürdeki çalışmaların sonucunda da kız ve erkek çocukları ile farklı nesnelerin eşleştirilmesi benzerlik göstermektedir.

İncelenen ders kitabında toplumun zihnindeki geleneksel aile yapısının sergilenmekte olduğu görülmüştür. Fakat bu kalıp yargıların ders kitapları aracılığ1 
ile okul sıralarından itibaren bireyleri şekillendirmesi, toplumların cinsiyetlere dair oluşturdukları yanlış yargıları değiştirememelerine yol açmaktadır. Erkek ve kız çocuklar ailenin, birlikte yaşanılan toplumun ve alınan eğitimin etkisi ile cinsiyetlerine bağlı olarak roller kazanırlar ve toplumsal cinsiyet kimliklerini edinirler. Bunun sonucunda evle alakalı işler ve çocuk bakımı gibi işler kadınlar için önemli hale gelirken, erkekler için ise işle ilgili roller daha önemli duruma gelir (Powell ve Greenhause, 2010: 1012). Geleneksel anlamda, aile yaşamı içerisinde işler ve sorumluluklar cinsiyet dikkate alınarak pay edilmektedir. Geleneksel aile bağlamında erkekler bahçe bakımı, tamir, gibi işlerden sorumlu olurken, kadınlar ise yemek pişirme, ev temizliği ve bulaşık yıkama gibi işlerden sorumlu olmaktadırlar (Şafak, Çopur ve Özkan, 2006). Çalışma, yapılan diğer çalışmaların sonuçları ile paralellik göstermektedir. Genel olarak kadınlar nazik, merhametli, yardımsever; erkekler ise daha ağır, dağınık ve sert davranışlar sergilemektedir. Aile içi rollerde ise kadın ev işleri ve alışverişle, erkek ise ev dışındaki işlerin yanı sıra tamir, boya-badana işleri ve çeşitli fiziki güç gerektiren işlerle sunulmuştur.

Çalışmanın kapsamında yer alan ders kitabını “Bireylerin Meslek Seçimlerine Göre Toplumsal Cinsiyet" kategorisine göre incelediğimizde içerikte yer alan kadın çocukları ve erkeklerin bazı meslek gruplarında ayrıştıkları tespit edilmiştir. Buna göre öğretmenlik ve hemşirelik mesleğinin daha çok kadınlarla; madencilik, balıkçılık, idarecilik gibi mesleklerin ise daha çok erkeklerle bütünleştirildiği görülmüştür. Ders kitapları aracılığı ile bireylere "her mesleği her cinsiyetin yapamayacağg” fikrinin aşılanması, toplumun belirli kalıplardan çıkamaması sonucunu doğurmaktadır. Gençlerin meslek tercihine yönelik anne-baba yaklaşımı, oyuncak ve renk yönlendirmesinden çok farklı değildir. Geçmiş yıllarda olduğu kadar katı olmamakla beraber toplumumuzda, "erkek mesleği" ve "kadın mesleği" anlayışı varlığını muhafaza etmektedir. Kandiyoti'ye (1982) göre, kadınlar da erkekler de daha çok toplumun kendilerine biçtiği mesleklere yönelmektedir. Sarı'ya göre (2011) hemşirelik kadınlık rolleri ile örtüştürülmüş ve kadınsı bir meslek olarak kurgulanmıştır. Birçok toplumda olduğu gibi ülkemizde de kadınların hosteslik, hemşirelik, öğretmenlik gibi anaç hizmetler ve özelliklerle tarif edilen işlerde çalışması; erkeklerin ise müteahhitlik, mühendislik, politikacılık ve müdürlük/ yöneticilik gibi daha çok liderlik, güç ve bağımsızlık gerektiren işlerde çalışması uygun görülmektedir.

Çalışma sırasında incelenen ders kitabında erkeklerin daha çok futbol, basketbol gibi topla oynanan oyunlarla ve satranç gibi zihinsel beceri gerektiren oyunlarla eşleştirildiği görülmüştür. Kız çocukları ise sek sek oynama, ip atlama ve çiçek toplama gibi oyunlarda ön plana çıkmıştır. White ise yapmış olduğu çalışmada toplumsal cinsiyet ilişkileri, erkek ve kadının yalnızca dişi ve eril bireyler olmadı̆̆ı, bununla beraber baba, anne, erkek çocuk ve kız çocuk, eş olduğunu gösteren bir sosyal ilişkiler toplamı anlamına gelmektedir (White, 2004). Sonucuna ulaşmış dişi erillik dişında toplumsal cinsiyetin yüklemiş olduğu farklı toplumsal rolle üzerinde durmuştur.

Çalışma kapsamında incelenen kitapta az da olsa kadını zayıf gösteren bazı ifadeler göze çarpmıştır. Benzer ifadelerin olduğu sonucuna daha önce yapılan çalışmalarda da ulaşılmıştır. Türk toplumunda sıklıkla kullanılan “Kız almak/ kız vermek" deyimleri kadını sahibi olan bir nesne gibi nitelendirirken, "karı gibi ağlamak" deyimiyse kadını zayıf bir şekilde göstermektedir. Buna benzer deyimlerin 
yıllarca söylenerek gelmesi de bahse konu rollerin ve algiların tekrardan üretimini sağlamaktadır (Tanrıtanır, 2005). Konu ile ilgili verilen örneklerde de görüldügüü üzere bu tip ifadelerin ders kitapları aracılığıyla yeni nesillere aktarılması cinsiyet ayrımcılığının zihinlerde hep var olmasına yol açacaktır.

Kitiş-Çınar (2013) "Ortaokul Türkçe Ders Kitaplarında Toplumsal Cinsiyet" adlı yüksek lisans çalışmasında, 2012/2013 eğitim-öğretim yılında MEB tarafından dağıtılan Türkçe ders ve öğrenci çalışma kitaplarını inceleyerek bu kitaplarda yer alan toplumsal cinsiyet öğelerini tespit etmeye çalışmıştır. Çalışma neticesinde ders kitaplarında toplumsal cinsiyet olgusunun yoğun bir şekilde hissedildiği, kadınların daha çok anne, öğretmen ve hemşire rolleriyle sunulduğu saptanmıştır. Esen ve Bağlı (2002), "İlköğretim ders kitaplarındaki kadın ve erkek şekillerine ilişkin bir inceleme" adlı makalelerinde ilköğretim ders kitaplarında kadın ve erkek şekillerini toplumsal cinsiyet bağlamında incelemişlerdir. Araştırmanın neticesinde kadınların ev ve ev çevresinde çocuklarıyla beraber, erkeklerin ise iş yaşamında kamusal ortamlarda gösterildiğini tespit etmişlerdir. Japonya'da lise okul kitaplarında toplumsal cinsiyet kavramını incelemeyi amaçlayan Ruddick (2010) İngilizce ders kitabında kadınların ailevi ve mesleki rollerde geleneksel bir şekilde temsil edildiğini, kitaplarda erkeklere oranla kadınların daha az görünürlüğe sahip olduğunu tespit etmiştir. Endonezya' da Damayanti (2014) ilköğretim okullarında yabancı dil öğrenimimde kullanılan İngilizce ders kitaplarını toplumsal cinsiyet açısından incelemeyi amaçlamıştır. Bu bağlamda kitaplardaki görsel ve metinlerde kadın ve erkek temsili analiz edilmiştir. Çalışma neticesinde ders kitaplarında kadın erkek temsilleri arasında orantısız bir durum olduğu tespit edilmiştir. Bahse konu ders kitaplarında kadınların erkeklerin takipçisi ve erkeklere bağımlı bir şeklinde sunulduğu saptanmıştır. İran'da Mousavi ve Gharbavi (2012) tarafından yürütülen bir çalışmada ise İngilizce yabancı dil ders kitaplarının toplumsal cinsiyet açısından incelenmesi amaçlanmıştır. Çalışma neticesinde yazarlar tarafından ders kitaplarındaki metin ve görsellerde erkeklerin kadınlara nazaran çok farklı alanlarda mesleki rollerde sunulduğu ve yine erkeklere nazaran kadınların görünürlüğünün düşük olduğu tespit edilmiştir. Konu ile ilgili bir diğer çalışma ise Özkan (2013)'a ait “İlköğretim Ders Kitaplarında Kadın Figürü" adlı çalışmadır. Özkan çalışmasını 2008-2009 eğitim yılında birinci kademe ilköğretim düzeyinde okutulan farklı ders ve düzeylerde 22 ders kitabı üzerinden yürütmüştür. Araştırma sonucunda 3 kitap dişındaki diğer bütün kitaplarda erkeklerin kadınlardan daha fazla temsil edildiğini ve kitaplardaki görsellerde cinsiyet ayrımcılığı yapıldığını tespit etmiştir. Singh (1998), Frazier ve Sadker (1973), Wright ve diğerleri (1977) yapmış oldukları çalışmalarda toplumsal cinsiyet kavramının kadın ve erkeklere farklı roller yüklendiğini tespit etmişlerdir.

Çalışmanın sonuçlarından yola çıkarak aşağıdaki önerilerde getirilebilir;

1. Ders kitaplarında toplumsal cinsiyet konusunda öğrencilerde yanlış anlama ve algılara yol açacak metin, görsel ve kavramların kullanılmamasına azami derecede dikkat edilmelidir.

2. Bireylerin toplumun cinsiyetlere göre ayırdı̆̆ı oyuncaklarla oynaması ve toplumun belirlediği gibi giyinmesi bireyleri kendi olmaktan çıkarabilir. Bu nedenle ders kitaplarında görsel ve metinlerde sunulan nesne ve renklerin cinsiyet ayrımcılığ1 taşımamasına özen gösterilmelidir. 
3. Ders kitaplarının toplum tarafından yanlış kodlanmış olan davranış kalıplarını öğrencilere aktarmamasına dikkat edilmelidir

4. Ders kitaplarının bireylere meslek seçme konusunda her iki cinsiyetin de ilgi, istek ve becerilerinin öncelikli olduğunu aktarmasına özen gösterilmelidir.

5. İncelenen ders kitaplarında tespit edilen insanoğlu, iş adamı, bilim adamı gibi ifadeler cinsiyet ayrımcılığı içermektedir. Bu sözcükler yerine cinsiyet ayrımcılığ1 içermeyen bilim insanı, iş insanı gibi ifadeler kullanılmalıdır.

\section{Kaynakça}

Arıkan, A. (2005). Age, gender and social class in elt coursebooks: a critical study. Hacettepe Üniversitesi Eğitim Fakültesi Dergisi, 28, 29-38.

Arslan, Ş. A. (2000). Ders kitaplarında cinsiyetçilik. T.C. Başbakanlık Kadının Statüsü ve Sorunları Genel Müdürlüğü.

Aziz, A. (2010). Sosyal bilimlerde araştırma yöntemleri ve teknikleri. Ankara: Nobel.

Büyüköztürk, Ş., Kılıç Çakmak, E., Akgün, Ö. E., Karadeniz, Ş. ve Demirel, F. (2015). Bilimsel Araştırma Yöntemleri. Ankara: Pegem Akademi.

Bowen, G. (2009). Document analysis as a qualitative research method. Qualitative Research Journal, 9(2), 27-40. https:/ / doi.org/10.3316/QRJ0902027

Çalapala, N. (1951). Güzel alfabe, İstanbul: Atlas.

Çınar, E. K. (2013). Ortaokul Türkçe ders kitaplarında toplumsal cinsiyet. Yayınlanmamış Yüksek Lisans Tezi, Pamukkale Üniversitesi Eğitim Bilimleri Enstitüsü.

Dalsar, F. (1950). Tabiat bilgisi 4. sınıf. İstanbul: Okul Kitapları Ltd. Şti.

Damayanti, I. L. (2014). Gender construction in visual images in textbooks for primary school students. Indonesian Journal of Applied Linguistics, 3(2), 100116. https://doi.org/10.17509/ijal.v3i2.272

Esen, Y. ve Bağlı, M. T. (2002). İlköğretim ders kitaplarındaki kadın ve erkek şekillerine ilişkin bir inceleme. Ankara Üniversitesi Ĕ̆itim Bilimleri Fakültesi Dergisi, 35(1-2), 143-154. https:/ / doi.org/10.1501/Egifak_0000000053

Frazier, N. and Sadker, M. (1973). Sexism in school and society. New York: Harper and Row Publications.

Freeman, R. and McElhinny. (1996). Language and gender. In Mckay, S.L. ve Hornberger, N.H. (Eds.) Sociolinguistics and LanguageTeaching (218-280). USA: Cambridge Universty Press. https:/ / doi.org/10.1017/CBO9780511551185.011

Giddens, A. (2008). Sosyoloji, haz. Cemal Güzel, Ankara: Ayraç.

Göçmen, İ. (1953). Yurttaşlık bilgisi-Ortaokul 3. Sınıf. İstanbul: Gün.

Gümüşoğlu, F. (1996). Ders kitaplarında cinsiyetçilik: 1928-1995. İstanbul: Kaynak Yayınları.

Gümüşoğlu, F. (2008). Ders kitaplarında toplumsal cinsiyet, tematik yazılar. Toplum ve Demokrasi, 2(4), 39-50.

Gümüşoğlu, F. (2016). Ders kitaplarında toplumsal cinsiyet-1928'den günümüze. İstanbul: Tarihçi Kitabevi.

Güneş, Ö. (2008). Ders kitaplarında toplumsal cinsiyet ayrımı (1990-2006). Journal of Society \& Social Work, 19(2), 81-95.

Gürşimşek, I. ve Günay, D. (2010). Çocuk kitaplarında cinsiyet rollerinin işlenişinde kullanılan dilsel ve dil dişı göstergelerin değerlendirilmesi. Buca Ĕ̆itim Fakültesi Dergisi, (18), 53-63. 
Helvacıoğlu, F. (1996). Ders kitaplarında cinsiyetçilik (1928-1995), İstanbul: Kaynak. İrge, Ş. (1952). Hayat bilgisi 3. sinıf. Ankara: Güney.

Kandiyoti, D. (1982). Urban change and women's roles in Turkey: An overview and evaluation. Sex roles, family and community in Turkey, 175.

Kılıç, L. K., ve Bircan, E. (2011). İlköğretim Türkçe ders kitaplarında ortaya çıkan toplumsal cinsiyet rolleri üzerine bir inceleme. Odü Sosyal Bilimler Araştırmaları Dergisi (Odüsobiad), 2(3), 129-148.

Kinalı, F. (1951). Hayat bilgisi 3. sinıf. Ankara: Örnek.

Kitiş-Çınar, E. (2013). Ortaokul Türkçe ders kitaplarında toplumsal cinsiyet. (Yayımlanmamış Yüksek Lisans Tezi). Pamukkale Üniversitesi, Eğitim Bilimleri Enstitüsü, Denizli.

Kurtuluş, F. (1952). Yurttaşlık bilgisi 4. sınıf. İstanbul: Milli Eğitim Basımevi.

Kurtuluş, F. (1953). Yurttaşlık bilgisi 5. sinıf. İstanbul: Kanaat Matbaası.

Kükrer, M., ve Kıbrıs, İ. (2017). Cedaw öncesi ve sonrası ortaokul türkçe ders kitaplarında yer alan toplumsal cinsiyet eşitliği faktörünün değerlendirilmesi. Abant İzzet Baysal Üniversitesi Ĕ̆itim Fakültesi Dergisi, 17(3), 1369-1383. https:/ / doi.org/10.17240/ aibuefd.2017.17.31178338836

Miles, M. B. and Huberman, A. M. (1994). Qualitative data analysis. (2nd ed.). California: SAGE.

Montgomery, B. M. (1986). Interpersonal attraction as a function of open communication and gender. Communication Research Reports, 3(1), 140-145.

Mousavi, S. A and Gharbavi, A. (2012). A content analysis of textbooks: investigating gender bias as a social prominence in 1ranian high school english textbooks. English Linguistics Research, 1(1), 42-49. https:/ / doi.org/10.5430/elr.v1n1p42

Narahara, M. M. (1998). Gender stereotypes in children's picture books. Long Beach: University of California.

Özkan, R. (2013). İlköğretim ders kitaplarında kadın figürü. The Journal of Academic Social Science Studies, 6(5), 617-631. http://dx.doi.org/10.9761/JASSS1567

Powell, G. N. and Greenhaus, J. H. (2010). Sex, gender, and decisions at the familywork interface. Journal of Management, 36(4),1011-1039. https:/ / doi.org/10.1177/0149206309350774

Ruddick, M. (2010). A gender analysis of an english language textbook used in a senior high school in japan. Niigata University of International and Information Studies Journal of Research, 13, 11-29.

Refik, A. (1928). Yurt bilgisi 4. sinıf. İstanbul: İkdam.

Sarı, Ö. (2011). Toplumsal cinsiyet ve mesleki rol ilişkisi: hemşirelik bölümünde okuyan erkek öğrenciler örneği. Erzincan Üniversitesi Sosyal Bilimler Enstitüsü Dergisi, (4), 2, 493-504.

Sarıtaş, E., ve Şahin, Ü. (2019). Hayat bilgisi ders kitaplarında toplumsal cinsiyet rolleri üzerine bir inceleme. Mehmet Akif Ersoy Üniversitesi Eğitim Fakültesi Dergisi, (48), 463-477.

Saydam, T. (2019). Türkçe ders kitaplarında toplumsal cinsiyetin farklı değişkenler açısından incelenmesi. (Yayımlanmamış Yüksek Lisans Tezi). Çanakkale Onsekiz Mart Üniversitesi Eğitim Bilimleri Enstitüsü, Çanakkale. 
Seçgin, F. (2012). Sosyal bilgiler dersinde toplumsal cinsiyet etkinliklerinin öğrencilerin algı ve tutumlarına etkisi. (Yayımlanmamış Doktora Tezi). Gazi Üniversitesi, Eğitim Bilimleri Enstitüsü, Ankara.

Singh, M. (1998). Gender issues in children "s literature. Clearinghouse on Reading. Retrieved April 12, 2010 from ERIC No: ED 424591.

Şafak, Ş. Çopur, Z. ve Özkan, M. (2006). Çocukların evle ilgili faaliyetlere harcadıkları zamanın incelenmesi. www.sdergi.hacettepe.edu.tr/sszcmao.pdf. (Erişim tarihi:09.11.2019).

Tanrıtanır, B. C. (2005). Türkçede dilin cinsiyete göre kullanımı. Sözlü Dil Yapısı, Haz. Mustafa Sarıca, İstanbul, Multilingual.

T.D.K, T. D. (2019). Türkçe sözlük. Ankara: Türk Dil Kurumu.

Tolan, B. (1991). Aile, cinsiyet ve cinsel roller. Aile Ansiklopedisi, Ankara: T.C. Başbakanlık Aile Araştırma Kurumu.

Üner, S. (2008). Toplumsal cinsiyet eşitliği, kadına yönelik aile içi şiddetle mücadelede temel eğitim seti. T.C. Başbakanlık Kadının Statüsü Genel Müdürlüğü, Avrupa Komisyonu Türkiye Delegasyonu, Ankara: Dumat Ofset.

Weitzman, L. J., Eifler, D., Hokada, E., and Ross, C. (1972). Sex-role socialization in picture books for preschool children. American journal of Sociology, 77(6), $1125-1150$.

White, J. B. (2004). Money makes us relatives: women's labor in urban Turkey. Routledge. Wright, S., Griffith, A., Butler, L., Chalmers, D., Egan, A. and White, R. (1977). About face. The Ontario Status of Women Council.

Yayli, D., ve Kitiş Çınar, E. (2014). Ortaokul Türkçe ders kitapları görsellerinde toplumsal cinsiyet. Electronic Turkish Studies, 9(5), 2075-2096. https:/ / doi.org/10.7827/TurkishStudies.6870

Yeşil, F. (2014). Ortaokul Türkçe ders kitaplarında cinsiyet ifadeleri ve toplumsal cinsiyet rolleri. Yayınlanmamış Yüksek Lisans Tezi. Marmara Üniversitesi, Eğitim Bilimleri Enstitüsü, İstanbul. YÖK Ulusal Tez Merkezi veri tabanından elde edildi. (Tez no: 412437)

Yıldırım, A. ve Şimşek, H. (2008). Sosyal bilimlerde nitel araştırma yöntemleri (6. Baskı). Ankara: Seçkin Yayıncılık.

Yıldız, M. (2013). İlkokul ve ortaokul din kültürü ve ahlak bilgisi kitapları görsellerinin toplumsal cinsiyet açısından incelenmesi. Dini Araştırmalar, 16(42), 143-165.

\section{Summary}

\section{Introduction}

The roles of gender are important for individuals in the socialization process and school, and textbooks are important in their formation. The school is an institution where gender identities are matured as the main place where cultural and social values are transferred and reproduced. It is very important to ensure the transfer of gender roles to new generations through two important lessons taught at primary school and social content and life knowledge that are intertwined with life and textbooks taught in these lessons. 
In the study, it was aimed to evaluate the 4th grade Social Studies textbook according to various variables in terms of gender. The determination of the role of the text and images in the content of the books in question to provide students with opinions about gender expressions and gender roles is among the main objectives of the study.

The study is an important one because, in order to determine how sensitive social studies textbooks, behave in terms of gender, and if there are deficiencies in these issues, the study constitutes a resource that can provide positive contributions to the people who will write textbooks and teachers who will apply them.

\section{Method}

In this study, document review method, which is one of the qualitative research methods, was used. The book, which was examined as a document in the research, is a Social Studies textbook that is deemed appropriate to be taught in the 4th grade of primary school, which was distributed by the Ministry of National Education during the 2019-2020 academic year. The data obtained from sources scanned throughout the study were evaluated using the content analysis method. In order to determine the gender coding in the texts and images in the 4th grade Social Studies textbook, categories related to the subject were determined. The contents of the Social Studies textbook were analysed according to these categories. In order to ensure the reliability of the analysis results, the encoding level between the coders was determined as $89 \%$ by making separate coding by two different studies.

\section{Results}

A total of 97 objects were reached in the text and images in the 4 th grade Social Studies textbook. The number of objects and colors paired with girls is 33, while the number of objects and colors paired with boys is 38 . The number of objects and colors paired with both genders is 26 .

A total of 35 behavioral patterns and family role items were reached in the text and images in the 4 th grade Social Studies textbook. Among them, the number of behavior patterns and family roles paired with girls is 29 , while the number of paired with boys is 19 . The number of behavior patterns and family roles paired with both sexes is 83 .

A total of 100 vocational items were reached in the text and images in the Social Studies textbook. While the number of occupations matched with girls is 25 , the number of those matched with boys is 35 . The number of occupations associated with both genders is 40 .

A total of 60 engagements and action items were reached in the text and images in the 4th grade Social Studies textbook. While the number of engagements and actions paired with girls is 17 , the number of paired men is 12 . The number of engagements and actions paired with both genders is 31 .

A total of 10 in-language stereotypes about gender were reached in the text and images in the 4th grade Social Studies textbook. Of these, the number of language expressions matched with girls is 6, while the number of those matched with boys is 4 . 


\section{Discussion}

In the studied textbooks, girls are seen with toys such as kitchenware and dolls, and boys with toys containing administration and power symbols such as aircraft, cars, and weapons. In the study conducted by Tolan (1991), it is stated that one of the most important elements that enable girls to socialize their identities within a traditionalist structure is toys and games. Girls are accustomed to household roles with small utensils and toys such as dolls from a very young age, while boys are directed to toys with administration and power symbols such as planes, cars, weapons.

In the examined textbooks, it was seen that the traditional family structure of the society is exhibited. Boys and girls acquire roles depending on the gender of the family, community and education, and acquire gender identities. As a result, jobs such as housework and childcare become important for women, while job-related roles become more important for men (Powell and Greenhause, 2010). Traditionally, jobs and responsibilities in family life are shared taking gender into account (Şafak, Çopur \& Özkan, 2006).

When we examined the textbooks included in the scope of the study according to the category of "Gender According to the Occupational Choices of the Individuals", it was found that the women / girls and men in the content differ in some occupational groups. Although it is not as rigid as in previous years, the understanding of "male profession" and "female profession" remains in our society. According to Kandiyoti (1982), both women and men tend more to the professions that society produces for them. According to Sar1 (2011), nursing is matched with femininity roles and it is designed as a feminine profession.

In the textbooks examined during the study, it was seen that men were mostly paired with games such as football, basketball, and games requiring mental skills such as chess. Girls have come to the fore in games such as bouncing, jumping rope and picking flowers. In the study conducted by White (2004), it was concluded that gender relations mean a total of social relationships which show that male and female are not only female and masculine individuals, but also father, mother, boy and girl, are spouses.

In the book analysed within the scope of the study, some expressions that make the woman weak are noticeable. The conclusion is that similar statements has been reached as in previous studies. The terms "selling / giving girls", which are frequently used in Turkish society, characterize the woman as an owner, while "crying like a woman" shows the woman weak. The fact that such idioms have been spoken for years provides the reproduction of the roles and perceptions in question (Tanritanir, 2005).

\section{Pedagogical Implications}

1. Maximum attention should be paid not to use texts, images and concepts that will cause misunderstandings and negative perceptions about gender in textbooks.

2. Individuals' playing with toys separated by society and dressing as determined by the society can make individuals unselfish. Therefore, care should be taken to ensure that objects and colors presented in textbooks and textbooks do not have gender discrimination. 
3. Care should be taken to ensure that textbooks tell individuals that their interests, desires and skills are prioritized in choosing a profession.

\section{Araştırmanın Etik Taahhüt Metni}

Yapılan bu çalışmada bilimsel, etik ve alıntı kurallarına uyulduğu; toplanan veriler üzerinde herhangi bir tahrifatın yapılmadığı, karşılaşılacak tüm etik ihlallerde “Cumhuriyet Uluslararası Eğitim Dergisi ve Editörünün” hiçbir sorumluluğunun olmadığı, tüm sorumluluğun Sorumlu Yazara/Yazarlara ait olduğu ve bu çalışmanın herhangi başka bir akademik yayın ortamına değerlendirme için gönderilmemiş olduğu sorumlu yazar tarafından taahhüt edilmiştir.

\section{Authors' Biodata/Yazar Bilgileri}

Kadir SÖNMEZ Bitlis Bölükyazı Köyü İlkokulu'nda sınıf öğretmeni olarak görev yapmaktadir.

Kadir Sönmez is working as a primary school teacher at Bitlis Bölükyazı Köyü Primary School.

Yurdal DİKMENLİ Kırşehir Ahi Evran Üniversitesi, Temel Eğitim Bölümü, Sınıf Eğitimi Anabilim Dalı'nda öğretim üyesi olarak görev yapmaktadır.

Yurdal Dikmenli works as a lecturer at Kırşehir Ahi Evran University, Department of Primary Education, Department of Primary School Teaching. 